\title{
Nasal myiasis in leprosy
}

\author{
S HUSAIN, G N MALAVIYA*, A GIRDHAR, \\ SREEVATSA \& B K GIRDHAR \\ Central Jalma Institute for Leprosy, PO Box 25, Tajganj, Agra \\ 282001, India
}

Accepted for publication 11 January 1991

\begin{abstract}
Summary Infestation of the nose with larvae of certain files can occur in leprosy patients. This results in severe distress and agony and can cause extensive tissue damage. The predisposing factors, clinical presentation and treatment is described.
\end{abstract}

\section{Introduction}

The term myiasis is derived from the Greek word 'Myia' meaning a fly. Myiasis is infestation of living tissues by larvae of flies. ${ }^{1}$

A proportion of leprosy patients having open ulcers and wounds get infested with larvae at some time or other. The larvae of certain flies (maggots), are seen frequently in nose and plantar ulcers; sometimes wounds in hands are also infested. ${ }^{2}$

We got interested in the problem for the following reasons: The nasal fistulae in leprosy patients, an outcome of neglected nasal myiasis, when presented at one of the clinical meetings surprised many. The number of patients that we see, their suffering and scant literature about the problem in leprosy patients, were other compelling reasons. Here we report our experience with nasal myiasis in leprosy patients and its management.

\section{Materials and methods}

The patients with nasal myiasis usually presented with facial cellulitis. They described a feeling of gnawing, crawling and irritation inside the nose and forehead, headache and nasal obstruction (Figure 1).

Blood mixed with mucus was seen dripping from the nose. Frank epistaxis was also seen, though rarely. Patients were disinterested and apathetic but in severe agony. At times a history of larvae dropping out of the nose was also obtained.

Some of the cases presented only with complaints of blood mixed with a thin mucus

* Correspondence. 


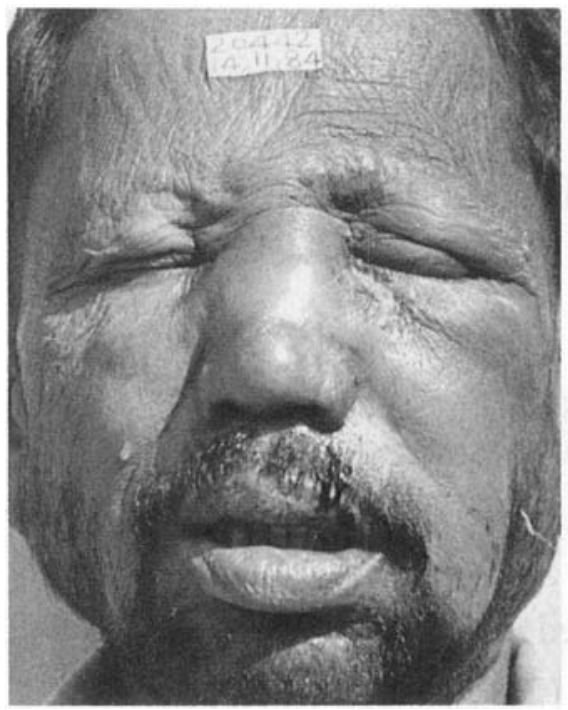

Figure 1. Cellulitis face.

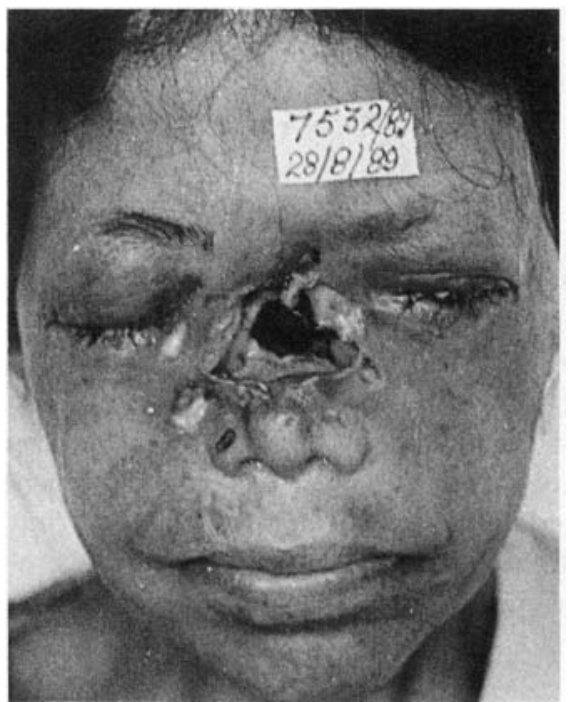

Figure 2. Extensive damage to nose.

discharge from the nose. Rarely they presented at an acute stage with extensive damage to the nasal tissues (Figure 2). Recurrent infestation was also seen.

The cases were hospitalized and their nasal cavity was irrigated with a turpentine: water mixture $(1: 10)$ twice daily, asking the patient to blow his nose immediately after irrigation. The nostrils were lightly plugged with a ribbon gauze soaked in a turpentine: water mixture after instilling a few drops of liquid paraffin. The procedure was continued till the nasal discharge subsided. 
In addition, the patients were given systemic antibiotics, Aspirin and diazepam orally till the cellulitis settled down. At the time of discharge from the hospital, patients were advised about routine nasal care.

\section{Observations}

The patients of lepromatous and borderline lepromatous leprosy were involved in this problem and the majority of them were seen between September and the early part of December when the mean temperatures were around $25^{\circ} \mathrm{C}$ and the humidity $80-90 \%$. Most of the cases were from the poor strata of society, middle-aged and usually males suffering from leprosy for 3 years or more.

The nasal cavity was completely free of maggots in $48-72 \mathrm{hr}$ after starting treatment. However, local cellulitis lasted for about 7-10 days.

\section{Discussion}

Nasal myiasis in leprosy has been reported by $\mathrm{RaO}^{5}$ and Bose ${ }^{6}$. Maggot infestation indicates a chronic debilitated condition of the patients. The patients were unhygienic, unhealthy and had foul smelling discharge from the nose.

Nasal involvement in leprosy is almost always seen in BL and LL types. ${ }^{3.4}$ In untreated cases, the nasal mucosa ulcerates and soon gets covered with a mucopurulent exudate which on secondary infection gives a foul odour and attracts flies. In due course, exudates dry up and adhere to mucosa forming a plug and giving a feeling of nasal obstruction. As a result, patients pick their nose to remove this plug, further injuring the nasal mucosa in the process. Atrophic rhinitis seen in lepromatous leprosy patients also predisposes to nasal myiasis. It is likely that patients contaminate their noses while picking or wiping with dirty clothes. The possibility of flies entering the nose during sleep and laying eggs, as suggested by Rao, ${ }^{5}$ seems unlikely because the flies are quite large.

To begin with the larvae, at least some of them if not all, live on putrid discharges and necrotic mucosa. Later as they grow, they burrow deeply, firmly anchoring themselves to the surrounding living tissues, the end result being tissue destruction.

Severe infestation, if neglected, can lead to extensive tissue destruction. Full thickness of the nasal wall when eaten away results in a nasal fistula (Figure 3). Occasionally the larvae burrow deep into the floor of the nasal cavity and eat away the bony palate to produce a palatal fistula (Figure 4). These fistulae are difficult to treat because of intense scarring. Nasal myiasis can prove fatal if cavernous sinus thrombosis sets in or the floor of the cranium is invaded.

It was observed that the number of live maggots removed from the nose is much less than from plantar ulcers. Probably the maggots are deeply embedded posteriorly in the nose. The dead maggots are coughed out mixed with discharges or else patients suffering from nasal myiasis present late when maggots start dropping off. Deep posterior burrowing of maggots makes their manual removal difficult.

Myiasis is common between September and December (postmonsoon season) in this part of the country though a few scattered cases can be seen throughout the year. The reason for this appears to be climatic with the prevalence of flies being high during that 


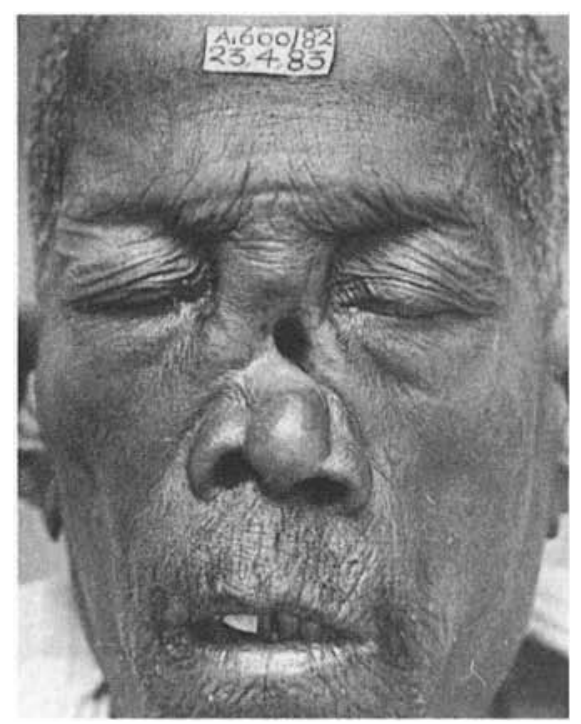

Figure 3. Nasal fistula.

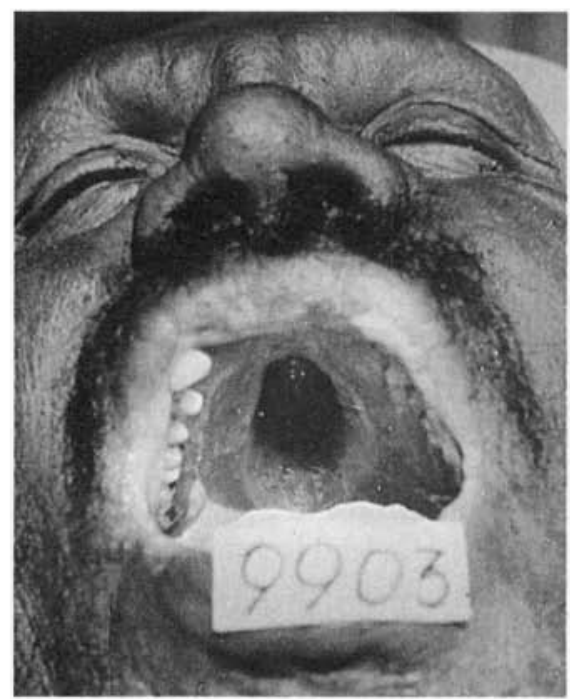

Figure 4. Palatal fistula.

time. Flesh-eating flies Chrysomia bezziana and Sarcophaga ruficornis of the order diptera were found to infest the cases of this study (Figures 5 and 6).

The aim of treatment is to remove the maggots, kill them to prevent maturation, promote wound healing and prevent secondary complications. ${ }^{7}$ Numerous medications have been used to clear the infestation. Some of these are: chloroform, ether, phenol, camphor, mercurous chloride, turpentine oil and eucalyptus oil.

The use of oily substances makes the surface slippery and interferes with the anchoring 


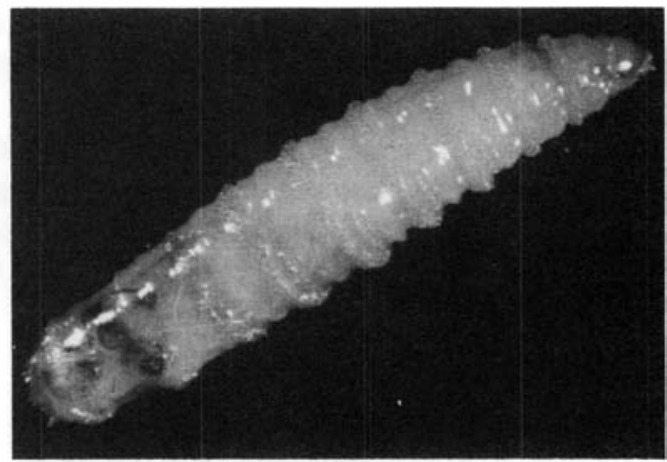

Figure 5. Maggot (larvae-C. bezziana).

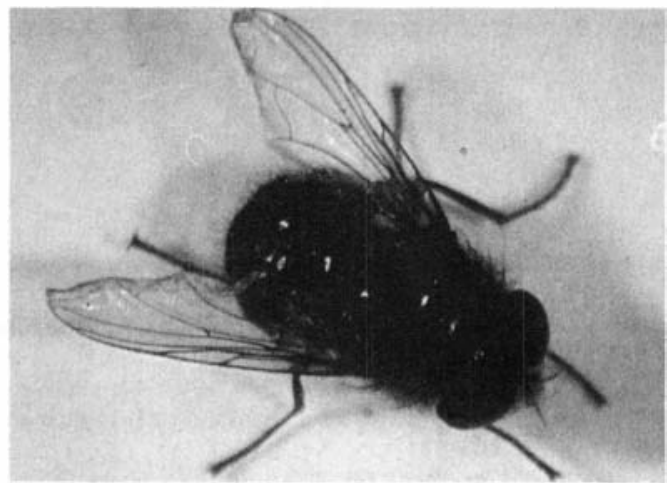

Figure 6. Fully grown fly (C. bezziana).

of larvae. An oily film prevents the larvae from breathing so that they come to the surface and fall off. Liquid paraffin is a nonirritating agent which serves the purpose well but in addition some larvicide like chloroform or a repellant like turpentine oil is also required. Irrigation with chloroform and/or a turpentine: water mixture followed by light packing with the same solution rapidly clears the nasal cavity. Instillation of a few drops of liquid paraffin in the nose prevents crust formation and helps healing.

These cases require systemic antibiotics and Aspirin to prevent further complications. Anxiolytics are needed to reduce restlessness. These drugs are continued till facial cellulitis subsides.

As stated earlier, sometimes an extensive invasion by maggots can lead to loss of the full thickness of nasal tissues producing defects-nasal fistulae.

These fistulae can vary greatly in size and are difficult to repair because of scarring in the surrounding tissues and persistent nasal ulcers. Other associated abnormalities like palatal perforation, collapse of nasal architecture, partial absorption of nasal bones and deformities like deviation of nasal columella might exist along with nasal fistulae.

Once the surrounding inflammation and oedema subsides and the tissues settle down, these fistulae can be repaired using standard techniques with suitable modifications. We preferred to use the locally available skin for such repairs because it was a better colour 
match and healed better. The results were satisfying to the patients, improving their appearance. Bone grafting was not done because the disease was active and there was risk of graft absorption.

To prevent nasal myiasis patients need to be educated about routine nasal care and hygiene. Instillation of oily nasal drops (liquid paraffin with eucalyptus oil) prevents crust formation and nasal obstruction. Partial closure of nostrils using local mucosal flaps (Young's procedure) ${ }^{8}$ has been tried by us successfully in a few cases to prevent recurrence.

\title{
Acknowledgments
}

The authors are indebted to Dr H Srinivasan, Director for his criticisms and help in preparing the manuscript. The secretarial assistance of Mr Shelandra Kulshrestha and the photographic work of $\mathrm{Mr}$ Hariom Agrawal and Neeraj Dubey is gratefully acknowledged.

\section{References}

1 Sahay LK. A study of maggots and their otorhinolaryngeal manifestations. Ind J Otolaryngol, 1959; 11: 1468.

2 Sreevatsa, Malaviya GN, Husain S, Girdhar A, Bhatt HR, Girdhar BK. Preliminary observations on myiasis in leprosy patients. Lepr Rev, 1990; 61: 375-8.

3 Barton RPE. The management of leprous rhinitis. Lepr Rev, 1973; 44: 186-91.

${ }^{4}$ Davey TF, Barton RPE. Leprous lesions of nose. In: Leprosy, Vol I. Dharmendra (ed.), Bombay: Kothari Medical Publishing House, 1978; pp. 168-73.

${ }^{5}$ Rao GR. Myiasis in lepers. Ind Med Gaz, 1929; 60: 380 quoted by Bose, DN. Lepr India, 1960; 32: 181-2.

6 Bose DN. Maggots in the nose of a lepromatous case of leprosy. Lepr India, 1960; 32: 181-2.

7 Weir N. Myiasis. In: Scott-Brown's Diseases of Ear, Nose and Throat, Vol 3. Ballantyne and Grooves (eds), London: Butterworths, 1979; pp. 204-6.

8 Young A. Closure of nostrils in atrophic rhinitis. J Laryngo Otol, 1967; 81: 514-24.

Lepr Rev (1991) 62, 389-94

\section{Myiase de la muqueuse nasale chez les lépreux}

\author{
S Husain, G N Malaviya, A Girdhar, Sreevatsa et B K Girdhar
}

Résumé Les larves de certaines mouches peuvent être la cause d'une infestation des muqueuses nasales chez les lépreux qui résultent en des douleurs graves et intenses et peut causer d'importantes lésions tissulaires. Les facteurs de prédisposition, le tableau clinique et le traitement sont décrits.

\section{Miasis nasal en la lepra}

\section{S Husain, G N Malaviya, A Girdhar, Sreevatsa y B K Girdhar}

Resumen La infestación de la nariz con larvas de ciertas moscas puede ser observada en pacientes con lepra. Esto resulta en gran dolor y agonía y puede causar un extenso daño al tejido. Se describen los factores de predisposición, la presentación clínica y el tratamiento. 